\title{
Public procurement and Covid-19 in Portugal: the particular case of the acquisition of institutional publicity related to the pandemic disease
}

\author{
Marco Caldeira
}

\begin{abstract}
In addition to several other exceptional legal measures adopted in regard to public procurement related to the pandemic of the disease Covid-19, the Government also enforced a specific regime for the acquisition of institutional publicity related or associated to Covid-19. However, this framework (set forth in article $2^{\text {nd-B }}$ of Decree-Law no. 10-A/2020, of March 13, added by DecreeLaw no. 20-A/2020, of May 6) is highly problematic and raises several issues, as, under the "cover" of a procurement regime, it is actually a direct public subsidization to the social media market, with a full upfront payment based on grounds of "urgency" that does not seem compatible with the public procurement rules.
\end{abstract}

\section{Keywords}

Covid-19; public procurement; social media; institutional advertising; urgent direct award.

1. Further to its health, social and economic consequences, the pandemic of the disease Covid-19 also had a huge impact in the legal systems throughout the world, including in Portugal. In fact, in order to fight the disease and prevent a larger-scale contamination, while trying to support the economic activities in a lockdown context, several legal measures were adopted, covering virtually all the sectors since labor regulation, data protection, insolvency, tax matters, administrative and judicial proceedings and, of course, public procurement. In this context, a new and exceptional framework was enforced, in order to allow awarding entities to enter into contracts for the execution of public works, the lease or purchase of goods and services related to Covid-19. A special reference shall be made to the regime enforced by Decree-Law no. 10-A/2020, of March 13, amended for several times (inter alia, by Law no. 1-A/2020, of March 19, by Decree-Law no. 10E/2020, of March 24, by Law no. 4-A/2020, of April 6, by Decree-Law no. 18/2020, of April 23, and by Decree-Law no. 20-A/2020, of May 6), related to public procurement in general, and which was also made applicable to specific acquisitions by means of special provisions (for example, related to artistic spectacles and cultural events, ex vi article 11 th of Decree-Law no. 10-I/2020, of March 26).

In broad terms, the special measures adopted by the Portuguese legislator consisted on the following:

a) The possibility of using direct award procedures on the grounds of "extreme urgency", for the execution of public works, lease or purchase of goods and services contracts related to Covid19 , regardless of the contract's price;

b) The possibility of using a simplified direct award (contracting upon an invoice or similar document) for the execution of public works, goods or services contracts, up to $€ 20.000$ (four times more than what is normally permitted by law);

c) The possibility of using a simplified direct award, to the necessary extent and for duly justified reasons of extreme urgency (which cannot be attributed to the awarding entity), regardless of 
the price, for the execution of contracts for the acquisition of the necessary equipment, goods and services for the prevention, containment, mitigation and treatment of Covid-19, or related purposes;

d) The possibility of executing contracts without the awarded bidder being obliged to submit its habilitation documents (e.g., the proof that it has no debts to the tax authorities) or to provide a performance bond to ensure the contract's fulfillment;

e) The dismissal of the Audit Court's prior clearance to the contracts (without prejudice of their submission to a further control);

f) The possibility of purchasing outside the scope of centralized framework agreements (even when acquisitions under said agreements are mandatory); and

g) The reduction of bureaucracy in regard to budgetary provisions and expenditure authorizations ${ }^{1}$.

2. However, along with this special regime for the procurement of works, goods and services related to Covid-19, the Government also enforced a specific regime for the acquisition of institutional publicity related or associated to Covid-19.

2.1. More specifically, by means of the abovementioned Decree-Law no. 20-A/2020, the Government allowed the use of the direct award procedures for the execution of contracts for the acquisition of institutional publicity related or associated to Covid-19, in national, regional and local media, through television, radio, printed and/or digital means, up to an overall amount of $€$ 15.000.000, VAT included (as per article $2^{\text {nd- }} \mathrm{B}$ of Decree-Law no. 10-A/2020, added by Decree-Law no. 20-A/2020). However, these direct awards can only be adopted to the extent strictly necessary and on duly grounded reasons of extreme urgency.

Pursuant to this regime, a group of contracting entities may, for an 18-month period, and based on duly grounded reasons of extreme urgency, purchase the strictly necessary instructional publicity on:

a) The public health pandemic situation and, among others, advertising on preventive and containment measures for the transmission of the virus, good social and hygiene practices, periodic reports and information on the public services in question;

b) Legislative measures adopted to contain the pandemic, as well as the public or social means available to rescue, monitor, inform or oversee;

c) Legislative measures adopted to balance the economy on a cross-sectoral or sectoral basis, as well as the public or social means available to rescue, monitor, inform or oversee;

\footnotetext{
${ }^{1}$ For a general overview and further developments on this subject, see, in particular, José Duarte Coimbra, Tiago Serrão and Marco Caldeira, Direito Administrativo da Emergência - Organização Administrativa, Procedimento Administrativo, Contratação Pública e Processo Administrativo na resposta à COVID-19, Almedina, 2020, pp. 87-120, as well as Miguel Assis Raimundo, "Covid 19 e contratação pública”, in Revista da Ordem dos Advogados, I/II, 2020, pp. 165-217, and Pedro Fernández Sánchez, "Medidas excepcionais de contratação pública para resposta à pandemia causada pela COVID-19”, in Inês Fernandes Godinho/Miguel Osório de Castro (ed.), COVID 19 e o Direito, Edições Universitárias Lusófonas, 2020, pp. 45-89.
} 
d) Legislative measures adopted for the progressive recovery of life and economy in a pandemic and post-pandemic context, as well as the public or social means available to rescue, monitor, inform or oversee;

e) Ancillary measures in the health area, such as the call for vaccination and the use of primary and emergency health services;

f) Measures in the area of education to inform the educational community of their rights and duties, deadlines, timetables, teaching and auxiliary resources as well as the means available to implement them;

g) Raising awareness on the prevention of forest fires in a pandemic year;

h) Social and humanitarian causes, such as domestic violence, violence against the elderly or minors, sharing of domestic and parental responsibilities, fighting discrimination, raising awareness to mental illness, and helplines and services in times of pandemic;

i) The promotion of media literacy and dissemination of cultural activities during and in the aftermath of the pandemic;

j) Other areas and matters serving similar purposes.

2.2. Through Resolution of the Council of Ministers no. 38-B/2020, of May 15, as amended by Declaration of Rectification no. 22/2020, of May 27, the Government (i)appointed the Government Shared Services Entity ("eSPap") as the grouping's representative ${ }^{2}$ and (ii) listed the entities who should benefit from these aids - which basically corresponded to every institution registered as a social media institutions towards the Portuguese Regulatory Authority for the Media ("ERC").

3. This legal framework raises several issues, both from a formal and from a substantial point of view.

3.1. From a formal standpoint, this framework appears, quite unexpectedly, as a provision destined to a "grouping of awarding entities" - when, on the contrary, we seem to be confronted, prima facie, with a brand new permission for the use of a direct award procedure to enter into a specific kind of contracts, with pre-determined companies and without prior clearance ("visto prévio") from the Audit Court ${ }^{3}$.

However, when taking a closer look, this legal framework becomes even more peculiar: in fact, more than a legal permission for launching direct award procedures, article $2^{\text {nd- }} \mathrm{B}$ of Decree-Law

\footnotetext{
2 Decree-Law no. 20-A/2020 provided that the Council of Ministers should appoint the grouping's representative and also establish the powers of each of the members.

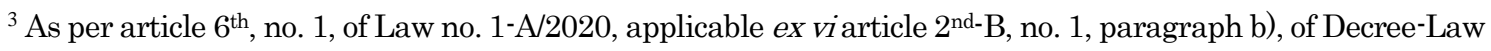
no. $10-\mathrm{A} / 2020$.

The Audit Court shall nevertheless proceed to a further control of the contracts executed under this legal framework.

In addition, the Resolution of the Council of Ministers no. 38-B/2020 foresees that the General Secretariat of the Presidency of the Council of Ministers shall issue a trimestral report regarding the performance of such contracts. However, no report seems to have been issued so far (or, if it has, it is not publicly available).
} 
no. 10-A/2020 constitutes, by itself, the actual decision of opening such a procurement procedure; and the subsequent Resolution of the Council of Ministers no. 38-B/2020 was, for all the relevant purposes, the awarding decision issued in that procedure - with the singularity that, in this case, no formal invitation was sent to any of the chosen entities and no formal bid was submitted by the latter ${ }^{4}$.

A deeper analysis of this framework leads us, therefore, to a surprising conclusion: under the "mask" of a specific provision for acquisition of institutional publicity by a grouping of awarding entities or a legal permission for the adoption of direct award procedures, the Government in fact proceeded to a direct subsidization of the sector of social media, by means of an anticipated purchase of institutional publicity ${ }^{5}$ : which is confirmed by the fact that the amount to be granted to each one of the awarded entities shall be fully paid in advance 6 and, as far it is known, it was calculated based on each entity's profits arising from commercial communications and their circulation profits during 2019's second trimester?

3.2. Even assuming that such a direct intervention of the Government in a regulated market does not raise any competition issues ${ }^{8}$, fact is that, in this particular case, public procurement concepts, mechanisms and framework seem to have been convoked to grant formal legitimacy to what was ipso facto a State aid to a specific sector (admittedly, in order to help the companies that operate in such market to survive the economic crisis, as acknowledged in the preamble of Decree-Law no. $20-\mathrm{A} / 2020)^{9}$.

\footnotetext{
${ }^{4}$ According with the information made publicly available, at least two entities - owners of the online journals Eco and Observador - have even rejected the financial support offered by the Government.

5 This anticipated purchase, for a whole 18-month period (see below), means that the performance of the service is not instantaneous (but rather continuous), i.e., each entity shall carry out several purchases until their respective "plafond" is sold out.
}

From this perspective, this becomes close to a framework agreement with several entities and that is performed throughout a typically long period of time by means of successive call-offs.

${ }^{6}$ As per paragraph 4 of Resolution of the Council of Ministers no. 38-B/2020.

${ }^{7}$ Similarly, on an equally revealing note, the amount of the total expenditure involved was previously settled at $€$ 15.000.000, which already included the applicable VAT, which also indicates that this was not the price to be paid in exchange of services to be provided in the future, but instead a fixed amount to be granted upfront to the social media institutions.

${ }^{8}$ As Portuguese law provides that no public help granted to private companies may affect the internal market in a significant way (as per article 65 ${ }^{\text {th }}$, no. 1, of the competition legal framework, enforced by Law no. 19/2012, of May 8).

However, as far it is known, the Portuguese Competition Authority was not consulted by the Government in this matter.

${ }^{9}$ And it is a particularly sensitive sector, subject to a specific constitutional framework destined to ensure the freedom of press and the independence of social media from the political power [see articles $38^{\text {th }}$, nos. 4 and 6 , and $39^{\text {th }}$, no. 1, paragraphs a) and c), of the Portuguese Constitution]. 
Furthermore, even from a strict public procurement perspective, this regime contains highly problematic provisions, which - now from a substantial point of view - may hinder the validity of the Government's conduct.

On the one hand, the "extreme urgency" invoked to allow direct award procedures is not compatible with an 18-month term: it is, in fact, quite difficult to argue that the "urgency" in the acquisition of institutional publicity may last for so long, as if during those 1,5 years would not be possible to launch a competitive procedure. As several authors rightly emphasize, pursuant to the proportionality principle, the appeal to the "urgency clause", for this purpose, shall be limited to the extent strictly necessary and cannot be subject to legal "manipulations" in order to cover situations in which no urgency actually exists ${ }^{10}$. And, according with the European Court of Justice, the exception of "extreme urgency" cannot be invoked for the award of contracts that take longer than they would have taken if a transparent, open or restricted, procedure had been used, including accelerated (open or restricted) procedures ${ }^{11}$.

On the other hand, the scope of the purchases in question is very broad, given that article $2^{\text {nd- }} \mathrm{B}$ of Decree-Law no. 10-A/2020 foresees that the publicity to be acquired may be destined to so many different goals as, for example, raising awareness on the prevention of forest fires in a pandemic year, social and humanitarian causes (e.g., domestic violence, violence against the elderly or minors, sharing of domestic and parental responsibilities, fighting discrimination, raising awareness to mental illness, and helplines and services in times of pandemic), promotion of media literacy and dissemination of cultural activities during and in the aftermath of the pandemic and other areas and matters serving similar purposes. These vague concepts and their remote connection with the pandemic show that the reference to Covid-19 is merely a pretext to simulate the "urgency" that would allow the use of direct procedures.

In view of this, there are solid grounds to sustain that, once the applicable thresholds are exceeded, the contracts executed for the acquisition of institutional publicity shall be deemed invalid, for breach of Directive 2014/24/EU of the European Parliament and of the Council, of February 26, $2014^{12}$.

This direct subsidization of social media entities, consisting on an advanced payment, even before any service was actually rendered, by means of a governmental decree-law, without any intervention whatsoever from the Parliament and the ERC, therefore raises serious doubts from a constitutional point of view, as duly noted by Pedro Fernández Sánchez (ob. cit., pp. 60 and 63).

${ }^{10}$ For this matter in general, see Miguel Assis Raimundo, "Catástrofes naturais e contratação pública", in Carla Amado Gomes (coord.) Direito(s) das Catástrofes Naturais, Almedina, 2012, pp. 260-261.

Specifically in regard to article $2^{\text {nd-B }}$ of Decree-Law no. 10-A/2020, see Pedro Fernández Sánchez, ob. cit., pp. $62-64$.

${ }^{11}$ As expressly reminded by the European Commission, in its Guidance from the European Commission on using the public procurement framework in the emergency situation related to the COVID-19 crisis (2020/C 108 I/01), of April 1 $1^{\text {st }}$.

${ }^{12}$ See Pedro Fernández Sánchez, ob. cit., pp. 62-64. 


\section{References}

- Coimbra, José Duarte, Serrão, Tiago, and Caldeira, Marco, Direito Administrativo da Emergência - Organização Administrativa, Procedimento Administrativo, Contratação Pública e Processo Administrativo na resposta à COVID-19, Almedina, 2020

- Raimundo, Miguel Assis, "Covid 19 e contratação pública”, in Revista da Ordem dos Advogados, I/II, 2020

- Raimundo, Miguel Assis, "Catástrofes naturais e contratação pública”, in Carla Amado Gomes (coord.) Direito(s) das Catástrofes Naturais, Almedina, 2012

- Sánchez, Pedro Fernández, "Medidas excepcionais de contratação pública para resposta à pandemia causada pela COVID-19”, in Inês Fernandes Godinho/Miguel Osório de Castro (ed.), COVID 19 e o Direito, Edições Universitárias Lusófonas, 2020 